\title{
Interacting effects of multiple factors on the morphological evolution of the meandering reaches downstream the Three Gorges Dam
}

\author{
HAN Jianqiao ${ }^{1,2},{ }^{*}$ ZHANG Wei ${ }^{2}$, FAN Yongyang ${ }^{3}$, YU Mengqing ${ }^{2}$ \\ 1. Institute of Soil and Water Conservation, Northwest A\&F University, Yangling 712100, Shaanxi, China; \\ 2. State Key Laboratory of Water Resources and Hydropower Engineering Science, Wuhan University, Wuhan \\ 430072, China; \\ 3. Changjiang Institute of Survey, Planning, Design and Research, Wuhan 430010, China
}

\begin{abstract}
Elucidating the influence of dams on fluvial processes can inform river protection and basin management. However, relatively few studies have focused on how multiple factors interact to affect the morphological evolution of meandering reaches. Using hydrological and topographical data, we analyzed the factors that influence and regulate the meandering reaches downstream the Three Gorges Dam (TGD). Our conclusions are as follows. (1) The meandering reaches can be classified into two types based on their evolution during the pre-dam period: $\mathrm{G} 1$ reaches, characterized by convex point bar erosion and concave channel deposition (CECD), and G2 reaches, characterized by convex point bar deposition and concave channel erosion (CDCE). Both reach types exhibited CECD features during the post-dam period. (2) Flow processes and sediment transport are the factors that caused serious erosion of the low beaches located in the convex point bars. However, changes in the river regime, river boundaries and jacking of Dongting Lake do not act as primary controls on the morphological evolution of the meandering reaches. (3) Flood discharges ranging from 20,000 to $25,000 \mathrm{~m}^{3} / \mathrm{s}$ result in greater erosion of convex point bars. The point bars become scoured if the durations of these flows, which are close to bankfull discharge, exceed 20 days. In addition, the reduction in bedload causes the decreasing of point bar siltation in the water-falling period. (4) During the post-dam period, flood abatement, the increased duration of discharges ranging from 20,000 to $25,000 \mathrm{~m}^{3} / \mathrm{s}$, and a significant reduction in sediment transport are the main factors that caused meandering reaches to show CECD features. Our results are relevant to other meandering reaches, where they can inform estimates of riverbed change, river management strategies and river protection.
\end{abstract}

Keywords: reaches downstream dams, meandering river, morphological evolution, Three Gorges Dam

Received: 2017-03-22 Accepted: 2017-05-02

Foundation: National Natural Science Foundation of China, No.51479146; Doctoral Foundation of Northwest A\&F University No.2452015337; National Key Research and Development Plan, No.2016YFC0402303, No.2016YFC0402101

Author: Han Jianqiao, $\mathrm{PhD}$, specialized in river geomorphology and numerical simulation of fluvial processes. E-mail: hjq13@163.com

*Corresponding author: Zhang Wei, PhD, E-mail: wzhang97082@whu.edu.cn 


\section{Introduction}

As one of the most common river patterns, the meandering river is closely associated with channel flood control and navigation (Edwards et al., 2016; Czapiga et al., 2015). The riverbed evolution of meandering rivers exhibits complex characteristics and is affected by multiple factors, including the upstream flow regime, channel boundaries, hydrological regime and downstream water stages (Bradley and Smith, 1984; Yao et al., 2010). Following dam impoundment, it is necessary to adapt to the changes in hydrological conditions and other factors in the downstream meandering reaches (Frascati and Lanzoni, 2009; Ibisate et $a l ., 2013)$. Investigation of these changes and the mechanisms by which meandering rivers respond to multiple factors will help facilitate river protection and management.

The phenomenon of bend bypassing and shoal cutting following dam construction has been documented in the Mississippi River, the Bollin River and the Han River (Harmar and Clifford, 2006; Luchi et al., 2010; Qin et al., 2009). During the 1980s, morphological regulation via bend bypassing and shoal cutting occurred in 11 of the 13 river bends in the Huangzhuang to Zekou reaches downstream the Danjiangkou Reservoir (Tan et al., 1996). The morphological regulation and its mechanisms have been given attention by many researchers (Li et al., 2013; Camporeale et al., 2008; Grenfell et al., 2012; Zhang et al., 2007). Different modes of shoal cutting are associated with various evolutionary processes. The flow conditions resulting from dam construction can alter riverbed processes, with the river making these adjustments to achieve optimal bend morphology. The changes in river boundaries are the main determining factor for bend bypassing, riverbed around convex bank is sourced while the development of concave bank is prevented by bank protection works, and greater channel curvature can cause erosion of point bars located on the convex side (Li et al., 2013; Hasegawa, 1989).

The lower Jingjiang River is a reach of the middle Yangtze River and has a predominant meandering pattern. The river bore the brunt of downstream erosion following the operation of the Three Gorges Dam (TGD) in 2003, as demonstrated by multiple examples of bend bypassing and shoal cutting in the meandering reaches downstream the dam (Li, Zeng and $\mathrm{Wu}, 2013$; Yao et al., 2011). These changes are difficult to explain because bank protection works was implemented during the 1990s and the river boundary was stable in the pre- and post-dam periods. Some researchers have suggested that a significant change in sediment load could cause bend bypassing in meandering reaches. Flow with a low sediment concentration will scour a convex point bar when sediment becomes trapped in the reservoir (He et $a l ., 2011)$. More water is directed from the concave bank to the convex bank due to deposition in the concave channel, which is clogged by bed load during the dry season, thus eroding the convex point bar (Han and Yang, 2000). Other studies have shown that bend bypassing is caused by changes in flow dynamics. For example, point bars can be eroded when the axis of flow shifts to the convex side (Hey et al., 2005). Sediment cannot be effectively transported from the concave bank to the convex bank by secondary circulation, resulting in a change in sediment transport mode (Albers and Steffler, 2007).

Previous studies have mainly focused on reductions in sediment concentration and changes in flow dynamics. However, these factors cannot explain the changes in the meandering reaches downstream the TGD, and little information is available on the interactions between multiple factors. Further study is needed to investigate the morphological evolution 
of the meandering reaches and the combined effects of multiple factors, including changes to the channel boundary, river regime, flow processes, and sediment transport. The objectives of this study are as follows: (1) to explore the morphological regulation of the meandering reaches and (2) to identify the effects of multiple factors on the morphological evolution of the meandering reaches downstream the TGD. These results will provide insight into how multiple interacting factors affect the morphology of the meandering reaches. The results will also inform estimates of riverbed change and strategies for river management and river protection in river reaches downstream of dams.

\section{Study area}

The Yangtze River is the longest river in China, with a catchment area of $1.8 \times 10^{6} \mathrm{~km}^{2}$. It is divided into upper, middle and lower reaches at Yichang, Hukou and Datong, respectively (Dai et al., 2016). The TGD, located $40 \mathrm{~km}$ upstream from Yichang, was constructed in 1992 and began operation in 2003. This project plays an important role in the management of the Yangtze River. The total storage capacity of the reservoir is $39.3 \times 10^{9} \mathrm{~m}^{3}$ and its flood control capacity is $22.15 \times 10^{9} \mathrm{~m}^{3}$ (Xu and Yan, 2010). The annual sediment load at Yichang decreased from $492 \times 10^{6} \mathrm{t}(1950-2002)$ to $43 \times 10^{6} \mathrm{t}(2003-2013)$.

Most of the meandering reaches occur on the Lower Jingjiang River (LJR), which extends from Ouchikou to Chenglingji. The total length, linear distance and bending rate of the LJR are $175.7 \mathrm{~km}, 84.5 \mathrm{~km}$ and 2.08 , respectively. The incoming flow and sediment within the LJR mainly originate from upstream of the TGD. A portion of the flow and sediment in the LJR is diverted into Dongting Lake through Ouchikou, Dongting Lake's outflow and the Jingjiang River outflow converge near Chenglingji. The bankfull discharge of the LJR is $22,000 \mathrm{~m}^{3} / \mathrm{s}$.

The LJR consists of eight meandering reaches, including the Tiaoguan, Laijiapu, Jianli, Fanzui, Xiongjiazhou, Qigongling, Qizhou and Shazui reaches (Figure 1). Main branch is regarded as meandering pattern in Jianli and Xiongjiazhou reach. The LJR is a severely eroded reach downstream the TGD and is generally representative of the meandering reaches in the middle Yangtze River.

\section{Data sources and methods}

\subsection{Data sources}

Daily discharge and sediment concentration data of Shashi and Jianli hydrological stations on the LJR were collected from the Changjiang Water Resources Commission (CWRC), China (www.cjh.com.cn). The sectional velocity distribution of the meandering reaches was obtained from the Changjiang Waterway Planning Design and Research Institute (CWPDRI), China. The topography data consist of sectional profiles measured in October 1996, October 2003 and October 2016.

\subsection{Classification of meandering reaches}

Based on evolutionary patterns during the pre-dam period, these meandering reaches can be classified into two types: type G1, characterized by convex point bar erosion and concave 


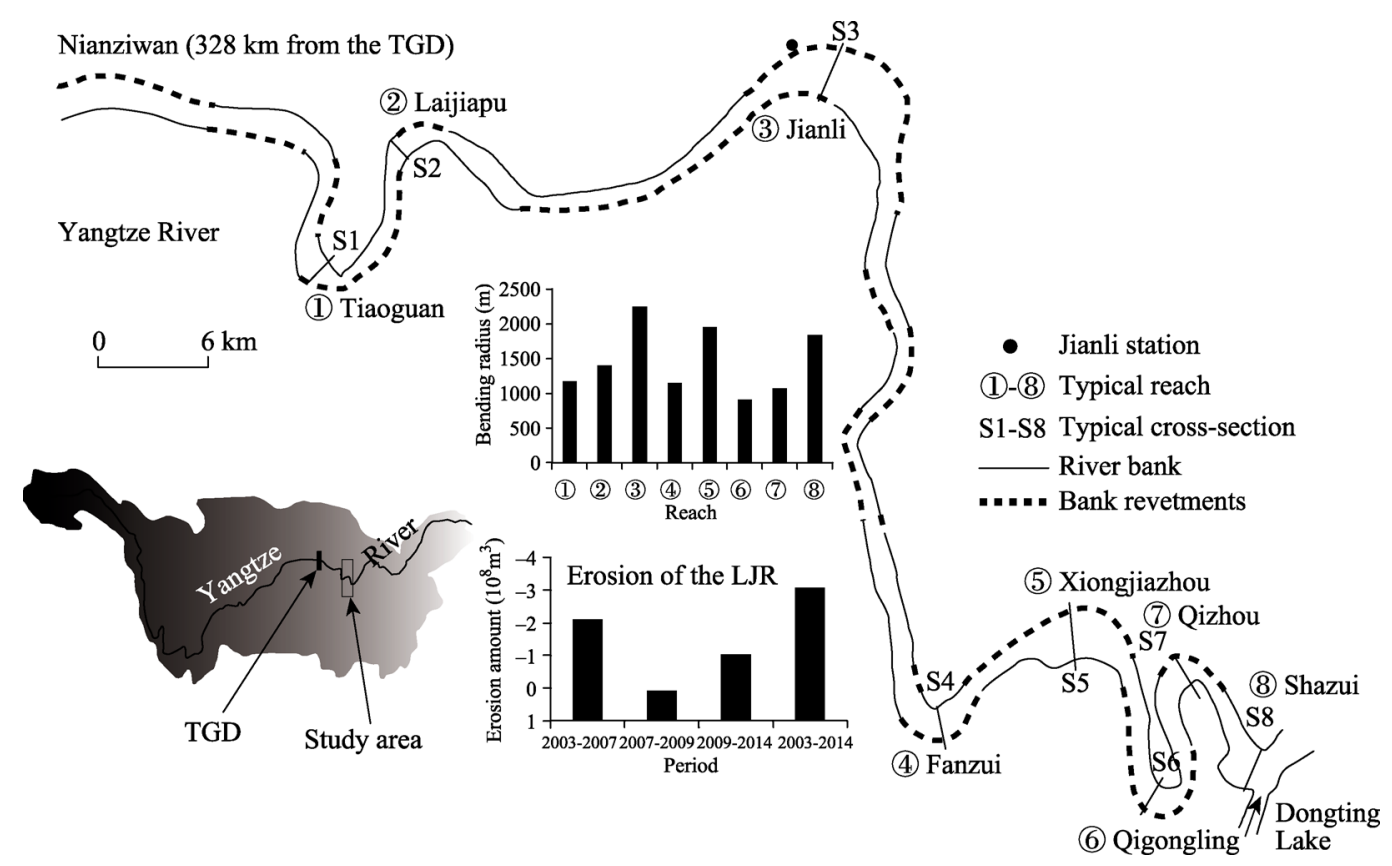

Figure 1 Study area, showing the meandering reaches downstream the Three Gorges Dam

Table 1 Sources of measurements

\begin{tabular}{cllc}
\hline \multicolumn{1}{c}{ Data type } & \multicolumn{1}{c}{ Station } & \multicolumn{1}{c}{ Measured time } & Sources \\
\hline Hydrologic data & Shashi & $2003-2013$ & CWRC \\
& Jianli & $1996-2015$ & CWPDRI \\
Sectional velocity & Six typical sections & August 2014, January 2015 & CWPDRI \\
Sectional profiles & Laijiapu reach & $2003-2016$ & CWRC \\
& Eight typical sections & 1996,2003, October 2016 \\
\hline
\end{tabular}

channel deposit (CECD), and type G2, characterized by convex point bar deposition and concave channel erosion (CDCE). Figure 2 shows the morphological patterns of the G1 and G2 reaches. The G1 type includes the Qigongling, Qizhou and Shazui reaches and the G2 type contains the Tiaoguan, Laijiapu, Fanzui, Xiongjiazhou and Jianli reaches.

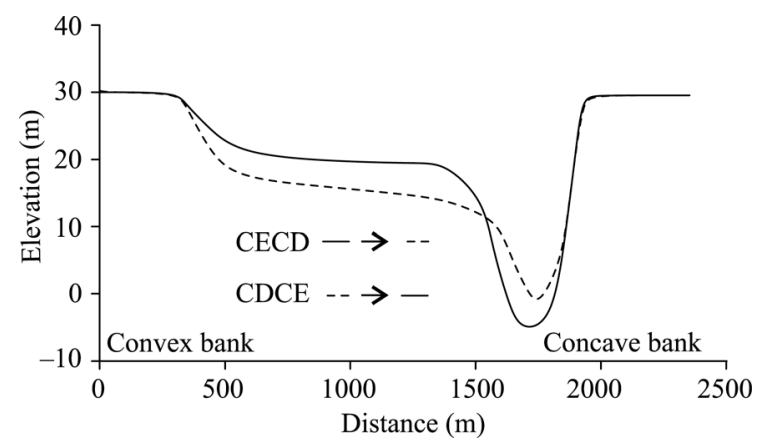

Figure 2 Morphological patterns of the G1 and G2 reaches

To analyze point bars and channel deformation, the channels were classified as low-flow, basic and bankfull channels. Low-flow channels had riverbed elevations below the low wa- 
ter stage. Basic channel corresponds to the water stage parallel with the point bar. Bankfull channels correspond to the bankfull stage. The discharges of the Jianli that correspond to each channel type are $5500 \mathrm{~m}^{3} / \mathrm{s}, 9000 \mathrm{~m}^{3} / \mathrm{s}$ and $22,000 \mathrm{~m}^{3} / \mathrm{s}$, respectively. Point bars were classified as low beach, high beach and floodplain (Figure 3 ).

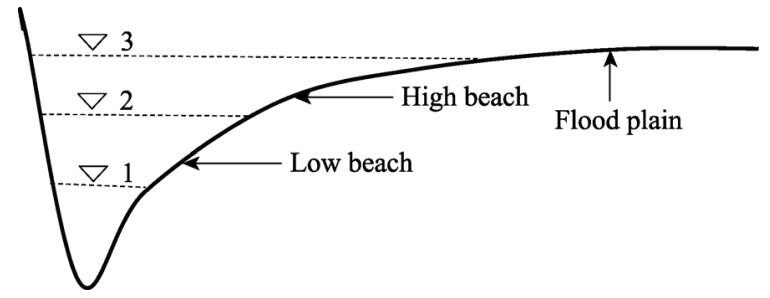

Figure 3 Schematic diagram of the channel divisions. The water stages representing low-flow channel, basic channel, and bankfull channel are indicated by 1,2 , and 3, respectively.

\subsection{Characterizing multiple factors}

Sectional profiles of eight typical cross-sections were compared to describe the riverbed evolution. The planform of thalweg was analyzed to investigate the influence of the river regime on riverbed processes. Similarly, the bending radius of the channel was calculated to assess the geomorphic effects of the river boundary during different periods.

The flow dynamic axis and sediment transport capacity were used to describe changes in flow. Flow dynamic axis was calculated as follows (Qin et al., 2009):

$$
R_{0}=0.053 R\left(\frac{Q^{2}}{g A}\right)^{0.348}
$$

where $R_{0}$ is the bending radius of the flow dynamic axis, $R$ is the bending radius of the channel, $Q$ is the discharge, and $A$ is the flow area. The sediment transport capacity was estimated using a simplifying indicator based on the following formula proposed by Zhang (Yuan et al., 2012):

$$
S=k\left(\frac{u^{3}}{w g h}\right)^{m}
$$

where $S$ is the sediment transport capacity, $u$ is the velocity, $h$ is the water depth, and $g$ is the acceleration due to gravity $\left(9.8 \mathrm{~m} / \mathrm{s}^{2}\right)$. The values of the coefficient $k$, the exponent $m$ and the settling velocity of the sediment $w$ can be considered constants. The simplifying indicator $u^{3} / h$ was used to represent the sediment transport capacity.

The bedload $\left(D_{50}>0.125 \mathrm{~mm}\right)$ runoff was estimated to explore the effects of changes in sediment on riverbed morphology.

\section{Results and discussion}

\subsection{Morphological evolution of meandering reaches}

Changes in the typical cross-sectional profiles of the G1 reaches are shown in Figure 4, showing the features caused by convex point bar erosion and concave channel deposition during the pre-dam (1996-2003) and post-dam periods (2003-2016). The floodplain, high beach and low beach experienced continuous erosion, and the thalweg migrated from a con- 
cave bank to a convex bank. For instance, in the Qizhou reach, the maximum scour depth of the convex bars exceeded $15 \mathrm{~m}$, the maximum silting thickness of the channel in the concave banks was greater than $10 \mathrm{~m}$, and the thalweg point shifted to a new, deeper channel. These phenomena also occurred in the Qigongling and Shazui reaches.

The G2 reaches showed different flow patterns from the G1 reaches during the pre-dam period: the convex point bar deposition and concave channel erosion occurred from 1996 to 2003. During the post-dam period, the G2 reaches evolved in similar ways to the G1 reaches: point bars in convex banks were scoured and deposition occurred in channels in the concave banks (Figure 5). For example, during the pre-dam period in the Tiaoguan reach, the sedimentation thickness of the low beach exceeded $7 \mathrm{~m}$, and the erosion depth of the concave channel was greater than $15 \mathrm{~m}$. By contrast, from 2003 to 2016, the erosion depth of the low beach reached $10 \mathrm{~m}$. Moreover, changes to the high beach were minor, the maximum depth of deposition in the channel exceeded $20 \mathrm{~m}$, and one mid-channel bar was generated in the original channel.

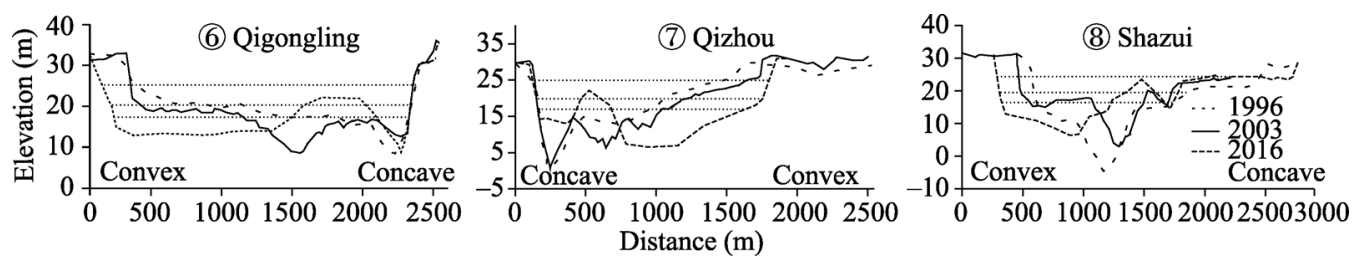

Figure 4 Typical cross-sectional profiles of G1 reaches during the pre- and post-dam periods
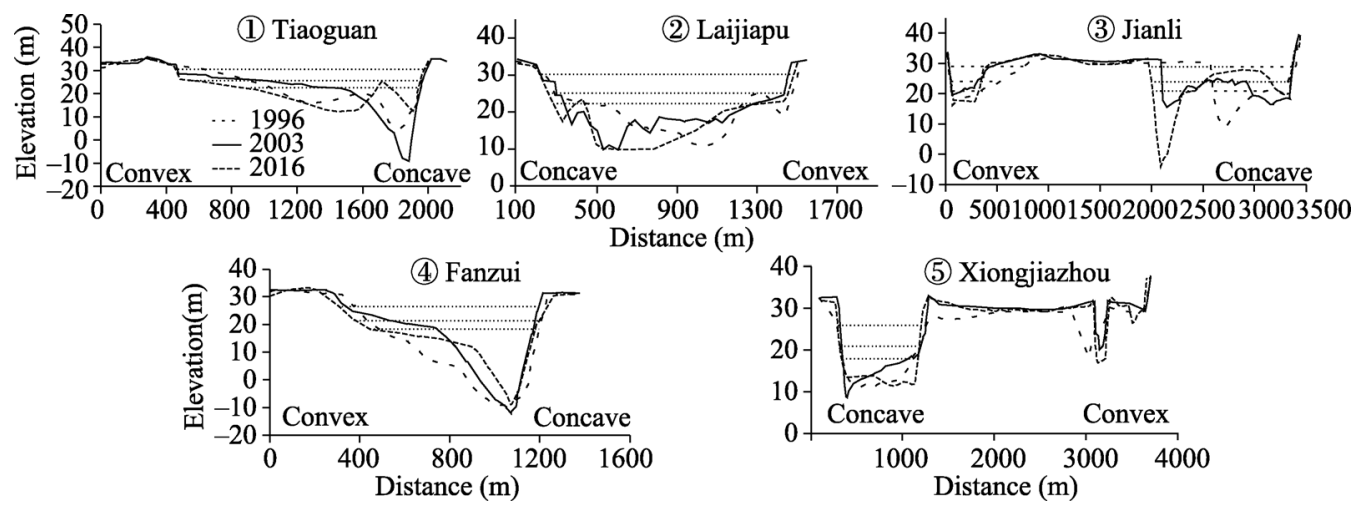

Figure 5 Typical cross-sectional profiles of the G2 reaches during the pre- and post-dam periods

\subsection{Effects of flow regime}

As shown in Figure 6, the flow regime of the upstream reach has a strong effect on the evolution of the G1 reaches downstream. The location of the thalweg in the river bends shifted to a left-right-left pattern after the flow regime changed in the upstream Qigongling, Qizhou and Shazui reaches.

For the $\mathrm{G} 2$ reaches, the thalweg location shifted to a right-left-right pattern in the Laijiapu reach, although the upstream flow regime was stable. However, this shift was consistent with flow regime changes in the upstream Fanzui reach, the location of the thalweg in the Fanzui reach moved to the left in the pre-dam period and then to the right in the post-dam period.

These results demonstrate that changes in the flow regime resulted in morphological 
changes to the meandering river reaches. However, both the G1 and G2 reaches showed CECD features regardless of changes in the upstream flow regime. Thus, the flow regime was not the key determining factor for the morphological evolution of the meandering reaches after TGD operation.

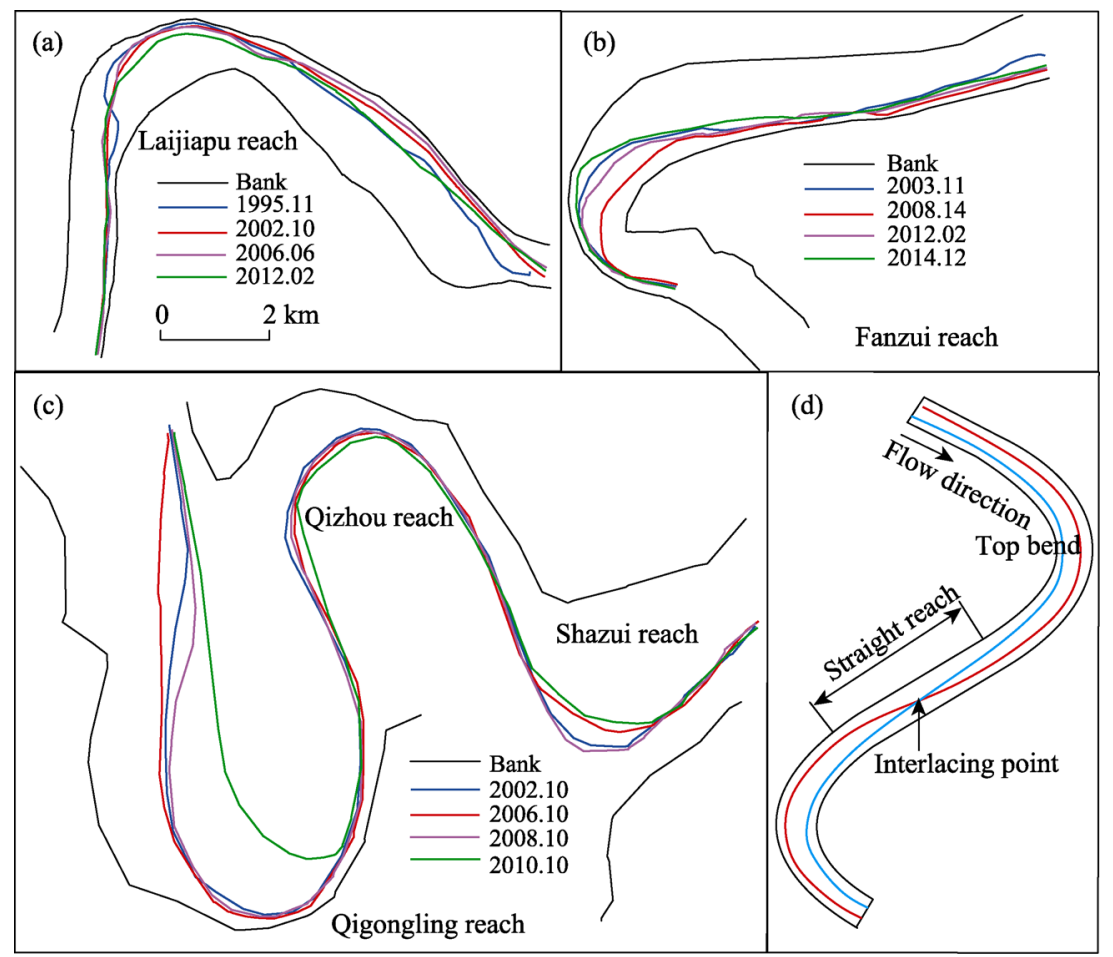

Figure 6 Changes in thalweg position in the meandering bends of the Lower Jingjiang River

\subsection{Effects of river boundaries}

In natural geomorphic processes, the river boundary plays an important role in the evolution of the meandering reaches. A small bending radius should result in convex point bar erosion and concave channel deposition. Lateral deformation is limited by bank protection projects, which alter the evolutionary regulation of riverbed morphology. Since 1998, many bank revetments have been installed along the LJR. Both the bank and bending radius were stable before and after the TGD. However, the morphology of the G2 reaches changed significantly after TGD impoundment, even though the river boundaries remained stable. Therefore, river boundaries do not control convex point bar erosion and concave channel deposition.

\subsection{Effects of flow processes}

Differences in the sediment transport capacity indicator $\left(u^{3} / h\right)$ for various discharges on the meandering reaches were used to compare the flow dynamics of convex and concave bank sides and thus the effect of flow processes on riverbed evolution (Figure 7). When the discharge increased from $7000 \mathrm{~m}^{3} / \mathrm{s}$ to $19,500 \mathrm{~m}^{3} / \mathrm{s}$, the $u^{3} / h$ values of the convex bank sides increased significantly and the peak area of sediment transport capacity moved to the concave bank side. Due to the sudden change of overbank characteristics of flow dynamics, the 
flow dynamics should experience a dramatic decline around the bankfull discharge $(22,000$ $\mathrm{m}^{3} / \mathrm{s}$ ). This relationship also affected the amount of daily erosion on the Jingjaing reach, the erosion intensity dropped to $5000 \mathrm{~m}^{3} / \mathrm{s}$ when the flow reached $25,000 \mathrm{~m}^{3} / \mathrm{s}$ (Figure 8 ). These results demonstrate that the critical discharges that result in convex point bar erosion range from 20,000 to $25,000 \mathrm{~m}^{3} / \mathrm{s}$, close to bankfull discharge.
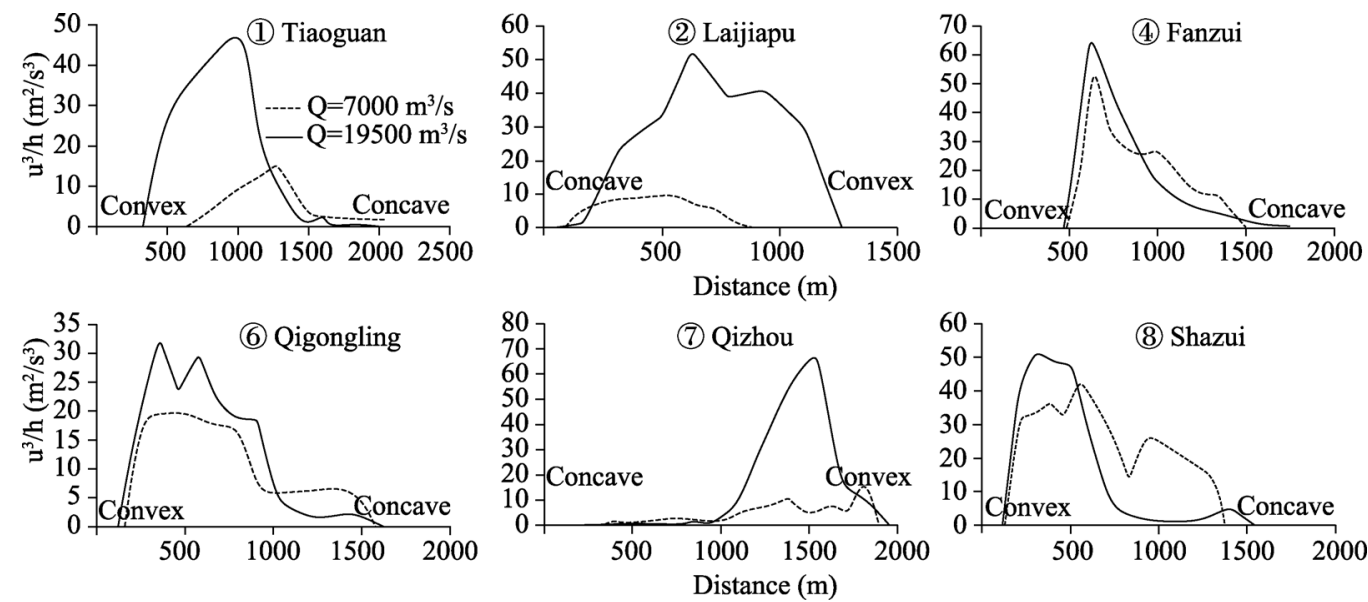

Figure 7 Changes in $u^{3} / h$ along the cross sections during different discharges in the Lower Jingjiang River

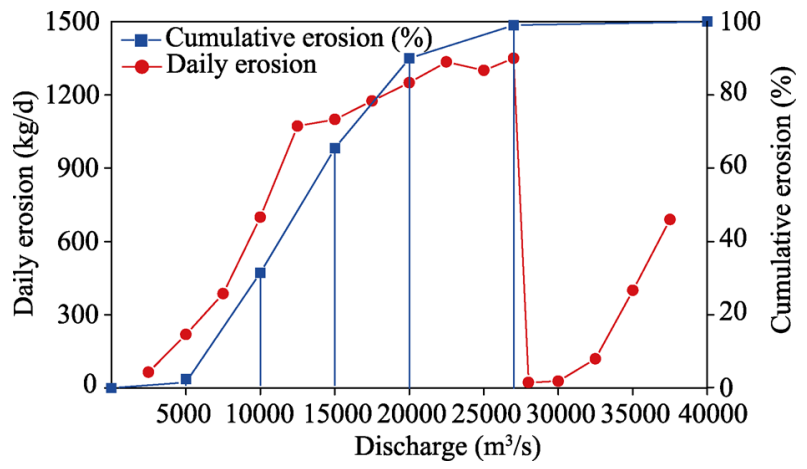

Figure 8 Erosion intensity caused by different discharges in the sandy bed of the Jingjiang River (Han et al., 2014)

Relationship between the convex point bar morphology and flow processes is exemplified in the Laijiapu reach. The flow regime and river boundaries did not change significantly and thus did not alter riverbed processes in the reach. The width of the high beach remained stable when a significant reduction in the flood discharge; the average duration of flood discharge exceeding $35,000 \mathrm{~m}^{3} / \mathrm{s}$ was reduced to 1 day during the post-dam period (Figure 9 and Table 2). In addition, the width of the low beach decreased during the post-dam period. However, during years in which discharges of $20,000-25,000 \mathrm{~m}^{3} / \mathrm{s}$ occurred less frequently (such as 2007, 2012 and 2016), the low beach experienced deposition. These results indicate that a discharge of $20,000-25,000 \mathrm{~m}^{3} / \mathrm{s}$ affects point bar evolution in meandering reaches. When the duration of discharge at this level is less than 20 days, siltation of the convex point bars tends to occur. Otherwise, for discharge durations greater than 20 days the point bars tend to become scoured. 
During the post-dam period, most years experienced almost all discharges of 20,000 $25,000 \mathrm{~m}^{3} / \mathrm{s}$ for more than 20 days. These altered flow processes, including flood abatement and the increased number of days with a discharge of $20,000-25,000 \mathrm{~m}^{3} / \mathrm{s}$, are the main factors controlling the morphological evolution of the meandering reaches.
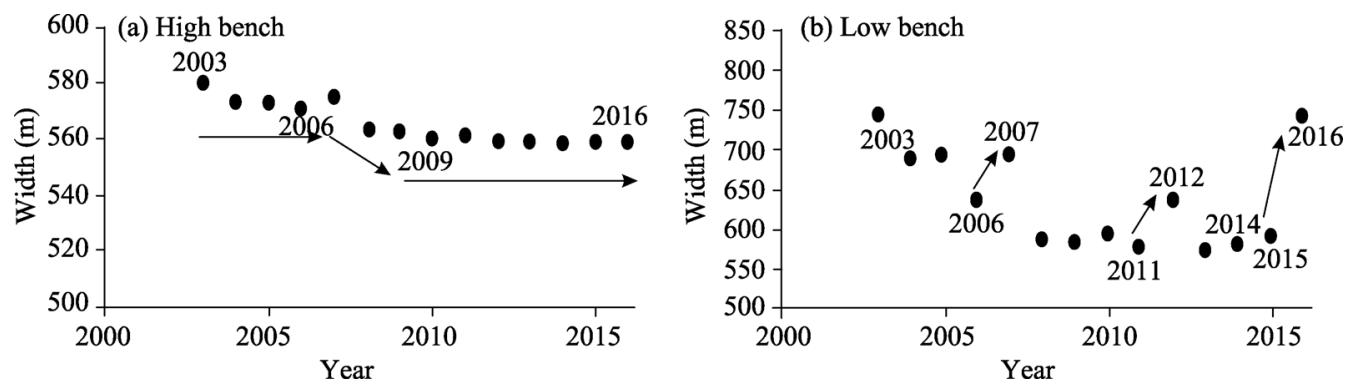

Figure 9 Changes in width of the high beach and low beach in the Laijiapu reach

Table 2 Durations of different discharge ranges at the Jianli station after impoundment of the TGR (days)

\begin{tabular}{lccccccc}
\hline Discharge $\left(\mathrm{m}^{3} / \mathrm{s}\right)$ & Average & 2003 & 2004 & 2005 & 2006 & 2007 & 2008 \\
\hline Bankfull discharge $(20,000-25,000)$ & 32 & 43 & 36 & 40 & 5 & 27 & 33 \\
Flood discharge $(>35,000)$ & 1 & 0 & 5 & 1 & 0 & 6 & 0 \\
\hline \hline Discharge $\left(\mathrm{m}^{3} / \mathrm{s}\right)$ & 2009 & 2010 & 2011 & 2012 & 2013 & 2014 & 2015 \\
\hline Bankfull discharge $(20,000-25,000)$ & 41 & 46 & 17 & 29 & 38 & 67 & 15 \\
Flood discharge $(>35,000)$ & 0 & 0 & 0 & 3 & 0 & 2 & 0 \\
\hline
\end{tabular}

\subsection{Effects of sediment transport}

With the recovery of sediment concentrations along the river, the coarse sediment load during the post-dam period resembled that of the pre-dam period at the Jianli station (Han et al., 2014). Both the G1 and G2 reaches exhibited the CECD features regardless of whether the sediment concentration had fully recovered. The reduction in sediment transport is not the determining factor on the morphological evolution of the meandering reaches. However, the decrease in bed load should increase the sediment transport dynamics of the unsaturated flow, causing serious erosion of the bankfull channel and decreasing of point bar deposition in water-falling period. Convex point bars will continue to scour if the bed sediment transport capacity decreases in the future.

\subsection{Effect of the jacking of Dongting Lake}

The flow dynamics of the G1 reaches located near Chenglingji are influenced by discharge from Dongting Lake, thus affecting the riverbed processes of meandering reaches. Existing research shows that no significant changes have occurred in the export channel of the Dongting Lake into the Yangtze River. The ratio of Dongting Lake discharge to river flow has not changed and the downstream water stage has been relatively stable (Feng et al., 2013). Thus, the jacking intensity of Dongting Lake has not changed significantly since impoundment of the TGD. Therefore, the jacking of Dongting Lake is not the critical factor for morphological evolution of meandering reaches. 


\section{Conclusions}

In summary, to understand the effects of dams on riverbed processes in meandering reaches, we investigated the effects of multiple factors on the morphological evolution of the meandering reaches downstream the TGD. During the pre-dam period, the G1 and G2 reaches were characterized by CECD and CDCE features, respectively. Both the G1 and G2 reaches showed the CECD behavior during the post-dam period. The bankfull channels in the meandering reaches downstream the TGD experienced scouring, and erosion was concentrated in low beaches located near convex point bars. The results of this study show that the flow regime, river boundaries and jacking of Dongting Lake are not determining factors for the morphological evolution of the meandering reaches. Rather, the riverbed processes were driven by flow processes and sediment transport. Erosion intensity was the greatest at discharges of 20,000-25,000 $\mathrm{m}^{3} / \mathrm{s}$, and when the flow durations were less than 20 days, siltation occurred at convex point bars; for durations greater than 20 days, the point bars were scoured. During the post-dam period, almost all years experienced discharges of $20,000-25,000 \mathrm{~m}^{3} / \mathrm{s}$ lasting more than 20 days. In addition, the reduction in bedload caused the decreasing of point bar siltation in water-falling period. Therefore, we attribute the change in the evolution of the meandering reaches to a significant decline in sediment load, a reduction in flood flows, and the increased duration of discharges ranging from 20,000 $\mathrm{m}^{3} / \mathrm{s}$ to $25,000 \mathrm{~m}^{3} / \mathrm{s}$. In the future, the meandering reaches should exhibit CECD features if the current management strategy of the TGD continues.

\section{References}

Albers C, Steffler P, 2007. Estimating transverse mixing in open channels due to secondary current-induced shear dispersion. Journal of Hydraulic Engineering, 133(2): 186-196.

Bradley C, Smith D G, 1984. Meandering channel response to altered flow regime: Milk River, Alberta and Montana. Water Resources Research, 20(12): 1913-1920.

Camporeale C, Perucca E, Ridolfi L, 2008. Significance of cutoff in meandering river dynamics. Journal of Geophysical Research Atmospheres, 113(F1): 548-562.

Czapiga M J, Smith V B, Nittrouer J A et al., 2015. Internal connectivity of meandering rivers: Statistical generalization of channel hydraulic geometry. Water Resources Research, 51(9): 7485-7500.

Dai Z, Fagherazzi S, Mei X et al., 2016. Decline in suspended sediment concentration delivered by the Changjiang (Yangtze) River into the East China Sea between 1956 and 2013. Geomorphology, 268: 123-132.

Edwards B L, Keim R F, Johnson E L et al., 2016. Geomorphic adjustment to hydrologic modifications along a meandering river: Implications for surface flooding on a floodplain. Geomorphology, 269: 149-159.

Feng L, Hu C, Chen X et al., 2013. Dramatic inundation changes of China's two largest freshwater lakes linked to the Three Gorges Dam. Environmental Science and Technology, 47(17): 9628-9634.

Frascati A, Lanzoni S, 2009. Morphodynamic regime and long-term evolution of meandering rivers. Journal of Geophysical Research Atmospheres, 114(F2): 179-180.

Grenfell M, Aalto R, Nicholas A, 2012. Chute channel dynamics in large, sand-bed meandering rivers. Earth Surface Processes and Landforms, 37(3): 315-331.

Han J, Sun Z, Huang Y et al., 2014. Features and causes of sediment deposition and erosion in Jingjiang reach after impoundment of the Three Gorges Project. Journal of Hydraulic Engineering, 45(3): 277-285. (in Chinese)

Han Q, Yang K, 2000. The evolution trend of Lower Jingjiang River after the impoundment of Three Gorges Pro- 
jects. Journal of Sediment Researches, (3): 1-11. (in Chinese)

Harmar O P, Clifford N J, 2006. Planform dynamics of the Lower Mississippi River. Earth Surface Processes and Landforms, 31(7): 825-843.

Hasegawa K, 1989. Universal bank erosion coefficient for meandering rivers. Journal of Hydraulic Engineering, 115(6): 744-765.

He G, Yao S, Jin Z, 2011. Study of atypical erosion of convex bank of river bend in Jingjiang Reach of Yangtze River. Yangtze River, 42(17): 1-3. (in Chinese)

Hey R D, Catmur S E, Sellin R H J et al., 2005. Behavior of meandering overbank channels with graded sand beds. Journal of Hydraulic Engineering, 131(8): 665-681.

Ibisate A, Díaz E, Ollero A et al., 2013. Channel response to multiple damming in a meandering river, middle and lower Aragón River (Spain). Hydrobiologia, 712(1): 5-23.

Li N, Zeng Y, Wu Z, 2013. Preliminary study of causes of mainstream bending of Qigongling Bend in Jingiiang reach of Yangtze River. Yangtze River, (1): 22-25. (in Chinese)

Li Z, Wang Z, Xu M et al., 2013. Patterns and mechanisms of neck cutoffs on meandering rivers. Journal of Tsinghua University (Science and Technology), 53(5): 618-624. (in Chinese)

Luchi R, Hooke J M, Zolezzi G et al., 2010. Width variations and mid-channel bar inception in meanders: River Bollin (UK). Geomorphology, 119(1/2): 1-8.

Qin L, Yu M, Tan G et al., 2009. Discussion on the relation between the change of the flow dynamic axis and the bend bypassing and shoal cutting in the bend river course. Journal of Hydrodynamics, 24(1): 29-35.

Tan G, Ning L, Li F, 1996. The mainstream movement and sandbars erosion in Hanjiang River from Huangzhuang to Zekou. Journal of Sediment Research, (2): 113-117. (in Chinese)

Xu J, Yan Y, 2010. Effect of reservoir construction on suspended sediment load in a large river system: Thresholds and complex response. Earth Surface Processes and Landforms, 35(14): 1666-1673.

Yao S, Huang L, Lu J, 2011. Review of research on river pattern in downstream of Three Gorges and Danjiangkou reservoirs. Yangtze River, 42(5): 5-10. (in Chinese)

Yao W, Zheng Y, Zhang M, 2010. Discussion on the mechanism of river meandering. Advances in Water Science, 21(4): 533-540. (in Chinese)

Yuan W, Yin D, Finlayson B et al., 2012. Assessing the potential for change in the middle Yangtze River channel following impoundment of the Three Gorges Dam. Geomorphology, 147/148: 27-34.

Zhang J, Chen L, Liu L et al., 2007. Perfect morphology of meandering river for middle and lower reaches of Hanjiang River. Engineering Journal of Wuhan University, 40(1): 37-41. (in Chinese) 